University of Nebraska - Lincoln

DigitalCommons@University of Nebraska - Lincoln

Faculty Publications in the Biological Sciences

Papers in the Biological Sciences

1979

\title{
Nocturnal Pollination of Abronia fragrans (Nyctaginaceae)
}

Kathleen H. Keeler

University of Nebraska - Lincoln, kkeeler1@unl.edu

Follow this and additional works at: https://digitalcommons.unl.edu/bioscifacpub

Part of the Botany Commons, and the Plant Biology Commons

Keeler, Kathleen H., "Nocturnal Pollination of Abronia fragrans (Nyctaginaceae)" (1979). Faculty Publications in the Biological Sciences. 279.

https://digitalcommons.unl.edu/bioscifacpub/279

This Article is brought to you for free and open access by the Papers in the Biological Sciences at DigitalCommons@University of Nebraska - Lincoln. It has been accepted for inclusion in Faculty Publications in the Biological Sciences by an authorized administrator of DigitalCommons@University of Nebraska - Lincoln. 
NOCTURNAL POLLINATION OF ABRONIA FRAGRANS (NYCTAGINACEAE).-Abronia fragrans Nutt. (Nyctaginaceae) is a white-flowered herb of dry sandy soils from Idaho and South Dakota to Arizona and Texas. It can be readily observed to fit a night-blooming, moth-pollinated syndrome (Faegri and van der Pijl, The principles of pollination ecology, 1971). This does not seem to have been noted: in all references to $A$. fragrans we could find, the only indication of nocturnal anthesis was the comment of Nelson (Handbook of Rocky Mountain plants, 1969), who observed that the fragrance was more noticeable at night. Tillett (Brittonia 19:299-327, 1967), working on Pacific species, suggested that the pink flowered $A$. umbellata was visited by moths, families Noctuidae and Sphingidae, as well as by day-flying insects, but did not identify any species. We captured the moth, Nycterophaeta luna (Morr.) (Noctuidae) pollinating $A$. fragrans in western Nebraska and confirmed the moth-pollination syndrome.

A small population of $A$. fragrans, variously called sweet sand verbena and prairie snowball, was observed at Cedar Point Biol. Stat, Ogallala, Nebraska (Keith Co.). Observations were made in late Jul. and early Aug. 1977. Abronia fragans appeared near the peak of flowering for this population, since there were numerous unopened buds. Howver, in 1976, this and another population at Ackley Valley Ranch, Keith Co., were through flowering by 1 Aug. Plants in Keith Co. were observed in flower discontinuously in late May and late Aug. 1978, apparently in response to rainfall.

Abronia fragrans is a perennial herb with several stems. The perianth consists of fused sepals, forming a narrow tube up to $2.5 \mathrm{~cm}$ long. The perianth is white and the heads of several flowers can be quite conspicuous. However, the flowers do not open until late afternoon (c. 1930 MDT) and are consequently inconspicuous during the day. The flowers emit a heavy sweet fragrance that was first detectable at approximately 2100. Nectar production apparently coincides with scent production because detectable amounts of nectar were not observed before 2100 . The nectar was produced at the base of the perianth just above the ovary, and up to $2.5 \mathrm{~cm}$ below the stigma and the four to five stamens, which are level with the opening of the perianth. These flowering characteristics are typical of adaptations to nocturnal pollinators which in north temperate regions would be moths (Faegri and van der Pijl 1971).

Moths of the species Nycterophaeta luna were observed visiting the flowers about 
2300. They came solitarily and visited several flowers per plant (although they were difficult to observe without disturbing them). Two moths were netted, one on $29 \mathrm{Jul}$. and one $10 \mathrm{Aug}$. 1977. They were identified by E. L. Todd, U.S. Dep. Agr. Both specimens were observed to have pollen on the proboscis. Thus $N$. luna can be concluded to be an effective pollinator.

The distribution of $N$. luna covers the Dakotas, Montana, Colorado, and Wyoming (Holland, The moth book, 1968). Thus, from the distribution data, $N$. luna could pollinate $A$. fragrans over the northern half of its range. Nothing is known of pollination in the southern half of the range. No other visitors were observed, but observations were not continuous all night, so the possibility of other visitors cannot be eliminated.

Of the approximately 35 species of Abronia in North America, at least 9 are white flowered. Moth pollination should be looked for in these species. Since $A$. umbellata is pink but predominstely night-risited (Tillett 1967) nocturnal pollination may be ever more widespread in the genus.

We would like to thank Mr. T. Miller for his help with the identification of the moth. We thenk Dr. R. Kaul for helpful comments on the manuscript. This study was carried out as part of a field ecology course at the Cedar Point Biol. Stat, Life Sci., Uniw. Nebraska-Lincoln.-Kathleen $\boldsymbol{H}$. Keeler and Mrra $S$. Fredricks, School of Life Sciences, University of Nebraska-Lincoln, Lincoln, NE 68588 . 